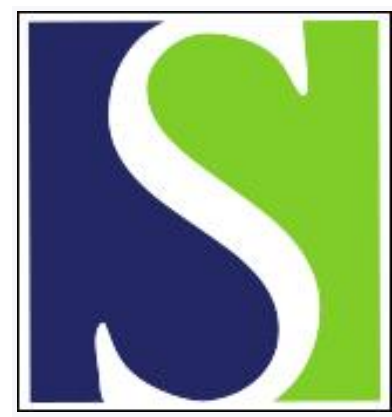

Scand J Work Environ Health 2006;32(6):431-442

https://doi.org/10.5271/sjweh.1049

Issue date: 31 Dec 2006

Work stress in the etiology of coronary heart disease-a meta-analysis

by Kivimäki $M$, Virtanen $M$, Elovainio $M$, Kouvonen $A$, Väänänen $A$, Vahtera J

Affiliation: Finnish Insitute of Occupational Health, Topeliuksenkatu 41 a A, FI-00250 Helsinki, Finland. mika.kivimaki@ttl.fi

Refers to the following texts of the Journal: $2004 ; 30(2): 85-128$ 1997;23(6):403-413

The following articles refer to this text: 2006;32(6):413-419; 2006;32(6):502-514; 2008;34(1):48-54; 2008;34(1):40-47; SJWEH Supplements 2008;(6):33-40; SJWEH Supplements 2008;(6):163-168; SJWEH Supplements 2008;(6):169-176; 2009;35(1):7-18; 2010;36(1):42-53; 2010;36(2):96-108; 2010;36(2):180-182; 2010;36(6):515-516; 2012;38(1):1-3; 2012;38(6):489-502; 2014;40(2):109-132; 2014;40(3):266-277; 2015;41(3):280-287; 2018;44(6):601-612; 2020;46(1):1-4; 2020;46(6):589-598; $2021 ; 47(7): 489-508 ; 2021 ; 47(7): 483-487$

Key terms: cardiovascular disease; coronary heart disease; effort-reward imbalance; ERI; etiology; job strain; meta-analysis; mortality; organizational justice; prospective cohort study; psychosocial factor; review; systematic review; work stress; working population

This article in PubMed: www.ncbi.nlm.nih.gov/pubmed/17173200

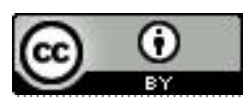




\title{
Work stress in the etiology of coronary heart disease-a meta-analysis
}

\author{
by Mika Kivimäki, PhD, ${ }^{1,2}$ Marianna Virtanen, PhD, ${ }^{2}$ Marko Elovainio, PhD, ${ }^{3}$ Anne Kouvonen, PhD, ${ }^{1}$ Ari \\ Väänänen, $P h D,{ }^{2}$ Jussi Vahtera, $M D^{2}$
}

\begin{abstract}
Kivimäki M, Virtanen M, Elovainio M, Kouvonen A, Väänänen A, Vahtera J. Work stress in the etiology of coronary heart disease —a meta-analysis. Scand J Work Environ Health 2006;32(6 special issue):431-442.
\end{abstract}

\begin{abstract}
Objectives This study focused on estimating the relative risk of coronary heart disease (CHD) in association with work stress, as indicated by the job-strain model, the effort-reward imbalance model, and the organizational injustice model.
\end{abstract}

Methods A systematic review and meta-analysis of prospective cohort studies were carried out. Studies were eligible if they had published a quantitative estimate of the association between work stress and incident CHD or cardiovascular mortality by January 2006.

Results Fourteen prospective cohort studies were identified. For a total of 83014 employees, the age- and gender-adjusted relative ratio of CHD for high versus low job strain was 1.43 [95\% confidence interval $(95 \%$ CI) 1.15-1.84], but the ratio decreased to 1.16 (95\% CI 0.94-1.43) after adjustment for risk factors and potential mediators. The age- and gender-adjusted risk ratio for a combination of high efforts and low rewards was 1.58 (95\% CI 0.84-2.97) for 11528 employees, and no reduction in the risk ratio was seen after further adjustments. For organizational injustice, the age- and gender-adjusted, and multiple-adjusted relative risks were 1.62 (95\% CI 1.24-2.13) and 1.47 (95\% CI 1.12-1.95), respectively, for a population of 7246 men and women. There was little standardization in the assessment of work stress within all three stress models, and significant heterogeneity in the effects of stress was observed between studies. Few studies were available for female samples.

Conclusions Observational data suggest an average 50\% excess risk for CHD among employees with work stress. Further research is needed to confirm that a reduction in work stress will lead to a reduction in CHD risk.

Key terms cardiovascular disease; effort-reward imbalance; job strain; mortality; organizational justice; prospective cohort study; psychosocial factors; systematic review; working population.

\begin{abstract}
Activation of the stress system in the hypothalamus and the brain stem helps the body to overcome the influence of short-term physical stressors. However, prolonged overactivity of these systems may cause wear and tear and play a role in coronary heart disease (CHD), infection, and accelerated aging (1). The recognition that the physiological reactions to stress cannot only protect, but also damage the body has provided a basis for epidemiologic research on work stress.
\end{abstract}

\section{Three models for work stress and coronary heart disease}

Work-stress models aim at describing factors that are likely to elicit harmful stress at work in a large proportion of employees. These factors are conceptualized at a level of generalization that allows for their identification in a wide range of occupations. The stress model most often cited and most widely tested is the two-dimensional job-strain model (2-4) (table 1). It proposes that employees who have high job demands and low control over work simultaneously are in a job-strain situation that, if prolonged, increases the risk of stressrelated diseases. Job control (or decision latitude) refers to both socially predetermined control over detailed aspects of task performance (eg, pace, quantity of work, policies and procedures, time of breaks, and scheduled hours) and skill discretion (ie, control over the use of skills by the worker). An expanded version of the job

1 University of Helsinki, Helsinki, Finland.

2 Finnish Institute of Occupational Health, Helsinki, Finland.

3 National Research and Development Centre for Health and Welfare, Helsinki, Finland.

Reprint requests to: Professor M Kivimäki, Finnish Insitute of Occupational Health, Topeliuksenkatu 41 a A, FI-00250 Helsinki, Finland. [E-mail: mika.kivimaki@ttl.fi] 
strain model adds social support to the model as a third component (5). The highest risk of illness is assumed to be related to iso-strain jobs, characterized by high demands, low job control, and low social support.

More recent developments in conceptualizations of work stress have broadened the view from proximal work characteristics to cover aspects of the person and the labor market context. A promising example is the effort-reward imbalance (ERI) model $(6,7)$ (table 1). This model maintains that an experienced imbalance between high effort spent at work and low reward received is particularly stressful, as this imbalance violates core expectations about reciprocity and adequate exchange at work. Not only high demands and challenges at work, but also overcommitment and heavy obligations in private life (eg, heavy debts) may contribute to a high expenditure of effort. Low rewards can be related to insufficient financial compensation from work, low esteem (eg, lack of help or acceptance by supervisors and colleagues), and poor career opportunities (no promotion prospects, job insecurity, and status inconsistency).

While effort-reward imbalance defines disproportionate costs for an employee in terms of gains received (ie, a distributive injustice condition) the latest research on work stress has also focused on the two remaining aspects of justice (8-10). Procedural justice indicates whether decision-making procedures include input from affected parties, are consistently applied, suppress bias, are accurate, are correctable, and are ethical (11). Relational justice refers to the treatment of workers with fairness, politeness, and consideration by supervisors (11). As justice is a fundamental value in social interaction and the organization of society (12-14), enduring problems with procedural and relational justice have been hypothesized to form an important source of stress at work, the organizational injustice model $(8,9,15)$ (table 1).

\section{Challenge of testing the models}

Several plausible mechanisms have been suggested through which long-term work stress may have an impact on the risk of CHD (16) (figure 1, part 1). They include prolonged overactivation and dysregulation of the autonomic nervous system and the hypothalamuspituitary-adrenal cortex (HPA) axis; both are assumed to increase disease risk, to disrupt existing disease processes, to act as triggers of acute events, such as heart attack, and to worsen prognosis. Stress is also assumed to drive susceptible persons towards the metabolic syndrome, characterized by insulin resistance, lipoprotein disturbances, reduced fibrolysis, and central obesity and to accelerate cellular aging (17-19). In addition to these and other direct biological effects, work stress may influence CHD risk indirectly through increased health risk behavior (20-23), lowered help-seeking behavior, and poor compliance with medical treatment (16).

Table 1. Sample items from scales assessing the three work-stress models.

\begin{tabular}{ll}
\hline Conceptual model & Sample item \\
\hline Job-strain model (iso-strain model) & $\begin{array}{l}\text { "Do you have to work very fast?" "I have a good deal of say in decisions about work" (reversed). "When you } \\
\text { are having difficulties at work, how often do you get help and support from your colleagues?" } \\
\text { "I am often pressured to work overtime." "Considering all my efforts and achievements, I receive the respect } \\
\text { and prestige I deserve at work" (reversed). "My job security is poor." } \\
\text { "Procedures are designed to hear the concerns of all those affected by the decision" (reversed). "Decisions are } \\
\text { made with consistency (the rules are the same for every employee)" (reversed). "My supervisor treats me } \\
\text { fairly" (reversed). }\end{array}$ \\
\hline
\end{tabular}

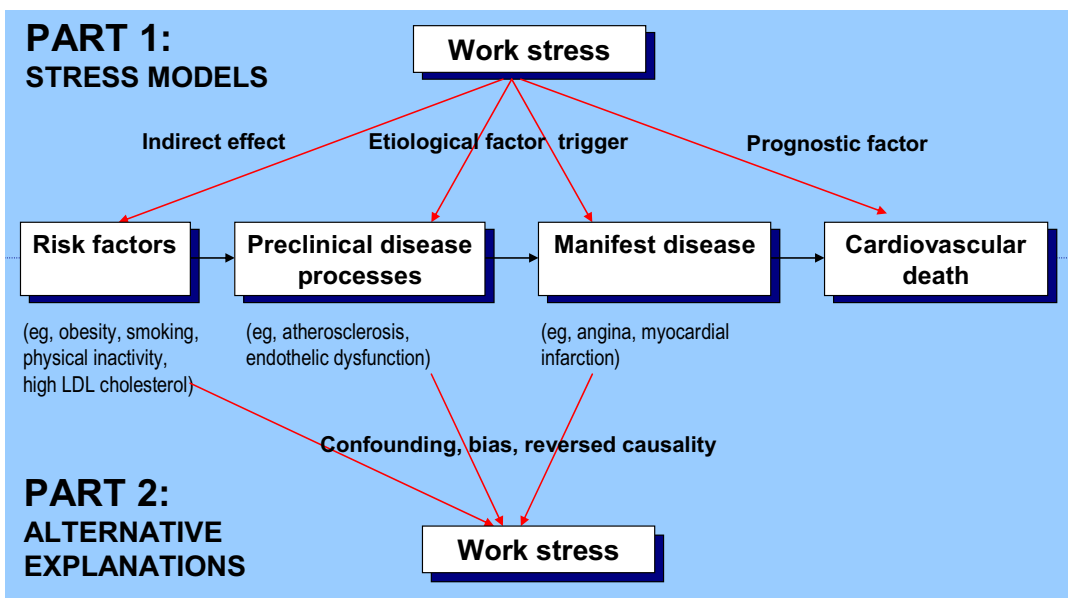

Figure 1. Hypothesized pathways from work stress to coronary heart disease and alternative explanations for this association. (LDL = low-density lipoprotein) 
However, demonstrating a causal relationship between work stress and CHD is not a simple task due to the possibilities for confounding, reversed causality, bias, and the difficulties with measurements (figure 1, part 2). Randomized controlled trials in this field of research are often impractical and unfeasible. CHD takes decades to develop, and it is associated with a large variety of risk factors in adulthood and from the preemployment period in childhood and adolescence. The possibility of type I error (false positive) arises when these risk factors are additionally associated with work stress. Reversed causality (eg, if early manifestations of CHD bias perceptions of stress) and publication bias would also increase the likelihood of such an error (24). In contrast, potential sources of false null findings (type II error) include a lack of an accurate quantification of long-term stress exposure (in particular if work stress was assessed at one point in time only) (25), insufficient statistical power to detect small or moderate effects, and the operation of the healthy worker effect (a selection bias in which healthier workers remain in stressful jobs and those with health problems drop out).

\section{The present review}

At least four narrative reviews on the job-strain model and the ERI model in the etiology of CHD have recently been published (26-29). We performed a systematic review and meta-analysis on updated evidence of these models and the injustice model. Compared with narrative reviews, systematic reviews with meta-analyses are strong in that the method of summarizing the data is transparent and reproducible, and it provides a quantitative estimate of the magnitude of the risk (30). However, as narrative reviews, meta-analyses are open to bias due to validity problems in the studies included. To decrease biases from confounding and reversed causality in the observed work stress-CHD relationships, we focused exclusively on prospective etiological cohort studies (ie, observational data with the strongest internal validity).

\section{Methods}

\section{Search strategy}

We identified potentially relevant studies through Medline (1979, the year the first work-stress model was published, to January 2006) using a combined text word and medical subheading (MeSH) search strategy. We entered a script, (job strain OR effort-reward OR justice) AND cardiovascular diseases [MeSH] AND prospective. We replicated this literature search with additional terms, such as "job control", "work stress", "job stress", and "psychosocial factors" to examine whether it would add to the identification of relevant studies. We continued searching for potentially suitable studies by using cross-references from original articles and reviews and by interviewing experts in the field (31). We screened titles, key words, and abstracts of the citations identified by the searches and obtained full copies of potentially suitable studies for further assessment.

\section{Criteria for inclusion}

We included prospective cohort studies if they had reported quantitative estimates and confidence intervals (or standard errors) of the relative risk (RR) for coronary heart disease or cardiovascular mortality associated with work stress. We excluded studies with no original data (eg, reviews), those lacking relevant measurement of the exposure or outcome, those that were not genuine prospective cohort studies, as well as overlapping papers reporting duplicate data for a same stress model. Among the excluded studies were also those analyzing the components of job strain (demands and control) separately but not the combination of the two, as the jobstrain model explicitly states that "cardiovascular risk results not from a single factor, but from the joint effects of the psychological demands of the work situation and the range of decision-making freedom with respect to task organization and skill usage ... [p 910]" (32). In cases of duplicate reports, we selected the one with a more valid assessment of the exposure or outcome or, if there was no difference in this respect, the paper first published.

\section{Study selection}

Two authors (MK, JV) independently assessed the studies identified by the search strategy to identify suitable cohort studies according to the aforementioned criteria. Details about each exclusion criterion were obtained independently and cross-checked for accuracy. All disagreements were resolved by consensus.

\section{Data analysis}

We used statistical software provided by Stata version 8 for a standard meta-analysis of observational studies $(33,34)$. We calculated summary estimates of relative risk for employees high versus low on work stress across the studies by means of a random effects method using inverse variance weighting. The random effects model assumes that the underlying effect of work stress may vary around some overall central effect and is not 
necessarily fixed across studies. This approach provides more conservative summary estimates than a fixed effects model assuming that the differences between study results are solely due to chance.

Separate summary estimates were obtained for each of the three stress models, for age- and gender-adjusted data, and for multiple-adjusted data. For the studies of the job-strain model, we made a forest plot in which the contribution of each study to the summary estimate was represented by the area of the box whose center was at the relative risk estimate for job strain from that study. The summary estimate was shown by the middle of a diamond (left and right extremes showing the corresponding $95 \%$ confidence intervals). A corresponding summary estimate was reported for the ERI and organizational justice models without forest plots due to the small number of studies. For each summary estimate, we assessed heterogeneity between the studies. We used meta-regression to assess the difference in combined relative risk estimates of CHD for work stress between men and women $(34,35)$.

To study the presence of publication bias, we evaluated and tested funnel plot asymmetry (available from the first author upon request), as suggested by Begg \& Mazumdar (36). Publication bias arises from the possibility that statistically significant findings are more likely to get published than nonsignificant results. Thus publication bias is assumed to be present if larger studies (in which smaller effects can be significant) report smaller effects than small studies (larger effects are needed for significant findings with these data).

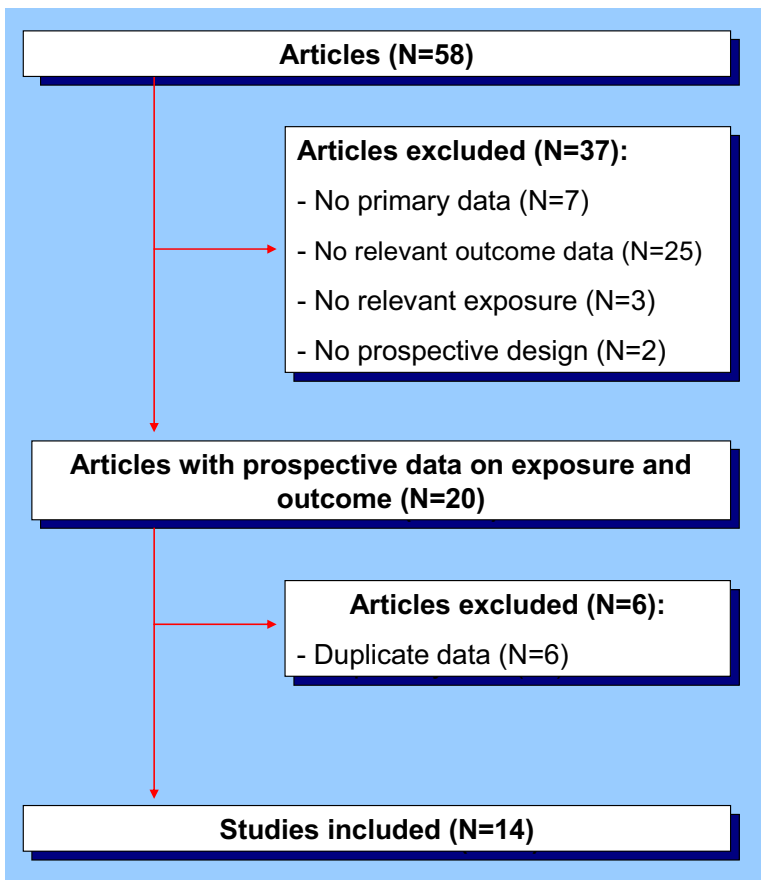

Figure 2. Flow chart of the search strategy.

\section{Results}

Our search strategy yielded 58 articles (51 from the electronic search, 5 from cross-references, and 2 from experts), of which 14 included independent primary data on both work stress, as an exposure variable, and CHD, as an outcome, and were prospective cohort studies (figure 2). Replication of the PubMed search with additional terms identified 202 other articles, but none of them met the inclusion criteria.

The 14 included studies comprised a total population of 83014 employees for the test of the job-strain model, 11528 employees for the test of the ERI model, and 7246 employees for the test of the organizational injustice model (table 2). Of the combined study population, $52 \%$ were men and $48 \%$ were women. The ages ranged between 17 and 65 years, except for the NHANES 1 study (37), the nurses' health study (38), and the Framingham offspring study (39), which also included older participants up to the ages of 74,71, and 77 years, respectively. Seven studies were from European countries (the United Kingdom, Sweden, Finland, Belgium, Germany, Denmark), five came from the United States, and one was from Japan. While the studies on job strain were from Europe, the United States and Japan, only European studies were available for the ERI and injustice models.

\section{Assessment of exposure}

A large variety of measurement instruments was used to assess work stressors in studies of the theoretical stress models. Typically the studies assessed work stress at one point in time only. Eleven independent studies tested the job-strain model (37-46). While the measure of job strain in all of these studies was generated by cross-tabulating the dichotomized or trichotomized scales of job demands and job control, the items included in these scales varied between the studies. Seven studies analyzed individual scores, but, in four studies, occupation-wise job-strain scores were imputed to the data (table 2).

In the four studies examining the ERI model, individual scores for effort-reward imbalance were constructed with two different approaches, first, by calculating the ratio of the effort and reward scales and then dividing this ratio into thirds or quartiles $(43,47)$ and, second, by cross-tabulating the dichotomized scales (6, 48). Also regarding the ERI model, the item content of the scales varied between the studies. Of the two ERI studies using the British Whitehall II cohort, Bosma et al (48) may have had a more comprehensive measure of ERI, but Kuper et al had a more objective CHD outcome (47). For this reason, two meta-analyses with three 
Table 2. Characteristics of studies on work-stress models and coronary heart disease (CHD). (ERI = effort-reward imbalance, CVD = cardiovascular disease)

\begin{tabular}{|c|c|c|c|c|c|c|c|c|c|}
\hline Study & $\begin{array}{l}\text { Cohort \& } \\
\text { country }\end{array}$ & $\begin{array}{l}\text { Partici- } \\
\text { pants } \\
\text { (N) }\end{array}$ & $\begin{array}{c}\text { Men } \\
(\%)\end{array}$ & $\begin{array}{c}\text { Age } \\
\text { (years) }\end{array}$ & $\begin{array}{l}\text { Stress } \\
\text { indicator }\end{array}$ & Outcome & $\begin{array}{l}\text { Dura- } \\
\text { tion }^{\text {a }} \\
\text { (years) }\end{array}$ & $\begin{array}{l}\text { Events } \\
(\mathrm{N})\end{array}$ & Adjustments \\
\hline $\begin{array}{l}\text { Reed et al, } \\
1989(40)\end{array}$ & $\begin{array}{l}\text { The Honolulu heart } \\
\text { program, Hawaii }\end{array}$ & 4737 & 100 & $45-65$ & $\begin{array}{l}\text { Job strain } \\
\text { (imputed) }\end{array}$ & Incident CHD & 18 & 359 & $\begin{array}{l}\text { Age, smoking, blood pressure, choleste- } \\
\text { rol, physical activity, glucose }\end{array}$ \\
\hline $\begin{array}{l}\text { Johnson et al, } \\
1989 \text { (41) }\end{array}$ & $\begin{array}{l}\text { Random sample of } \\
\text { male working } \\
\text { population, Sweden }\end{array}$ & 7219 & 100 & $25-65$ & $\begin{array}{l}\text { Iso-strain } \\
\text { (imputed) }\end{array}$ & CVD death & 9 & 193 & Age \\
\hline $\begin{array}{l}\text { Siegrist et } \\
\text { al, } 1990(6)\end{array}$ & $\begin{array}{l}\text { Blue-collar men, } \\
\text { Germany }\end{array}$ & 416 & 100 & $25-55$ & ERI & Incident CHD & 6.5 & 21 & $\begin{array}{l}\text { Age, body mass index, blood pressure, } \\
\text { cholesterol }\end{array}$ \\
\hline $\begin{array}{l}\text { Alterman et } \\
\text { al, } 1994(42)\end{array}$ & $\begin{array}{l}\text { The Chicago Western } \\
\text { Electric study, } \\
\text { United States }\end{array}$ & 1683 & 100 & $38-56$ & $\begin{array}{l}\text { Job strain } \\
\text { (imputed) }\end{array}$ & CHD death & 25 & 115 & $\begin{array}{l}\text { Age, blood pressure, cholesterol, smoking, } \\
\text { alcohol consumption, family history of CVD } \\
\text { disease, education, occupational class }\end{array}$ \\
\hline $\begin{array}{l}\text { Steenland et } \\
\text { al, } 1997(37)\end{array}$ & $\begin{array}{l}\text { The NHANES1 study, } \\
\text { United States }\end{array}$ & 3575 & 100 & $25-74$ & $\begin{array}{l}\text { Job strain } \\
\text { (imputed) }\end{array}$ & Incident CHD & 16 & 519 & $\begin{array}{l}\text { Age, blood pressure, education, body mass } \\
\text { index, cholesterol, smoking, diabetes }\end{array}$ \\
\hline $\begin{array}{l}\text { Bosma et al, } \\
1998 \text { (48) }\end{array}$ & $\begin{array}{l}\text { The Whitehall II } \\
\text { study, United } \\
\text { Kingdom }\end{array}$ & 4393 & 67 & $35-55$ & $E R I^{b}$ & Incident CHD & 5.3 & 251 & $\begin{array}{l}\text { Age, gender, grade, negative affectivity, } \\
\text { smoking, cholesterol, hypertension, body } \\
\text { mass index }\end{array}$ \\
\hline $\begin{array}{l}\text { Kivimäki et al, } \\
2002 \text { (43) }\end{array}$ & $\begin{array}{l}\text { Industrial employ- } \\
\text { ees, Finland }\end{array}$ & 812 & 67 & $17-65$ & $\begin{array}{l}\text { Job strain, } \\
\text { ERI }\end{array}$ & CVD death & 25.6 & 73 & $\begin{array}{l}\text { Age, gender, occupational group, smoking, } \\
\text { physical activity, blood pressure, } \\
\text { cholesterol, body mass index }\end{array}$ \\
\hline $\begin{array}{l}\text { Lee et al, } \\
2002(38)\end{array}$ & $\begin{array}{l}\text { The nurses' health } \\
\text { study, United States }\end{array}$ & 35038 & 0 & $46-71$ & Job strain & Incident CHD & 4 & 146 & $\begin{array}{l}\text { Age, follow-up period, smoking, alcohol } \\
\text { consumption, hypertension, diabetes, } \\
\text { hypercholesterolemia, menopausal status, } \\
\text { medication, diet, physical activity, parental } \\
\text { history of myocardial infarction, educa- } \\
\text { tion, marital status, husband's education }\end{array}$ \\
\hline $\begin{array}{l}\text { Kuper et al, } \\
2002(47) ; \\
\text { Kuper \& Mar- } \\
\text { mot, } 2003(44)\end{array}$ & $\begin{array}{l}\text { The Whitehall II } \\
\text { study, United } \\
\text { Kingdom }\end{array}$ & 10300 & 67 & $35-55$ & $\begin{array}{l}\text { Job strain, } \\
\text { ERI }\end{array}$ & Incident CHD & 11 & 916 & $\begin{array}{l}\text { Age, gender, grade, cholesterol, body } \\
\text { mass index, smoking, hypertension, } \\
\text { physical activity, alcohol consumption }\end{array}$ \\
\hline $\begin{array}{l}\text { Eaker et al, } \\
2004(39)\end{array}$ & $\begin{array}{l}\text { The Framingham } \\
\text { offspring study, } \\
\text { United States }\end{array}$ & 3039 & 56 & $18-77$ & Job strain & Incident CHD & 10 & 149 & $\begin{array}{l}\text { Age, blood pressure, cholesterol, body } \\
\text { mass index, smoking, diabetes }\end{array}$ \\
\hline $\begin{array}{l}\text { Bacquer et al, } \\
2005 \text { (45) }\end{array}$ & $\begin{array}{l}\text { The Belgian job } \\
\text { stress project, } \\
\text { Belgium }\end{array}$ & 14337 & 100 & $35-59$ & $\begin{array}{l}\text { Job strain, } \\
\text { iso-strain }\end{array}$ & Incident CHD & 3.2 & 87 & $\begin{array}{l}\text { Age, education, body mass index, smoking, } \\
\text { diabetes, blood pressure, cholesterol, } \\
\text { occupation }\end{array}$ \\
\hline $\begin{array}{l}\text { Uchiyama et } \\
\text { al, } 2005 \text { (46) }\end{array}$ & $\begin{array}{l}\text { The hypertension } \\
\text { follow-up group } \\
\text { study, Japan }\end{array}$ & 1615 & 56 & $40-65$ & Job strain & $\begin{array}{l}\text { Incident CVD } \\
\text { event }\end{array}$ & 5.6 & 47 & $\begin{array}{l}\text { Age, blood pressure, body mass index, } \\
\text { cholesterol, proteinuria, left ventricular } \\
\text { hypertrophy, ischemic ST-T change, atrial } \\
\text { fibrillation, family history of stroke }\end{array}$ \\
\hline $\begin{array}{l}\text { Kivimäki et al, } \\
2005 \text { (8) }\end{array}$ & $\begin{array}{l}\text { Men from the } \\
\text { Whitehall II study, } \\
\text { United Kingdom }\end{array}$ & 6442 & 100 & $35-55$ & $\begin{array}{l}\text { Justice at } \\
\text { work }\end{array}$ & Incident $\mathrm{CHD}$ & 8.7 & 237 & $\begin{array}{l}\text { Age, grade, cholesterol, body mass index, } \\
\text { hypertension, smoking, alcohol consump- } \\
\text { tion, physical activity, job strain, ERI }\end{array}$ \\
\hline $\begin{array}{l}\text { Netterström } \\
\text { et al, } 2006 \\
\text { (49) }\end{array}$ & $\begin{array}{l}\text { Men from the } \\
\text { MONICA II study, } \\
\text { Denmark }\end{array}$ & 659 & 100 & $30-60$ & Job strain & Incident IHD & $\begin{array}{l}13 \\
\text { (maxi- } \\
\text { mum) }\end{array}$ & 47 & $\begin{array}{l}\text { Age, socioeconomic position, marital } \\
\text { status, cholesterol, triglycerides, body } \\
\text { mass index, blood pressure, smoking, } \\
\text { alcohol consumption, physical activity }\end{array}$ \\
\hline $\begin{array}{l}\text { Elovainio et } \\
\text { al, } 2006 \\
(15)\end{array}$ & $\begin{array}{l}\text { Industrial employees, } \\
\text { Finland }\end{array}$ & 804 & 67 & $17-65$ & $\begin{array}{l}\text { Justice at } \\
\text { work }\end{array}$ & CVD death & 25.6 & 73 & $\begin{array}{l}\text { Age, gender, occupational group, smoking, } \\
\text { physical activity, blood pressure, choleste- } \\
\text { rol, body mass index, job strain, ERI }\end{array}$ \\
\hline
\end{tabular}

a Duration of follow-up.

${ }^{b}$ Bosma et al, 1998 (48) and Kuper et al, 2002 (47) are from a same cohort, the first having a more comprehensive assessment of ERI, but the latter having a more objective assessment of outcome. Thus two meta-analyses were conducted for ERI, one including Bosma et al but not Kuper et al and the other including Kuper et al but not Bosma et al.

independent studies were conducted for ERI, one including Bosma et al but not Kuper et al and the other including Kuper et al but not Bosma et al.

Two studies examined the association between organizational injustice and CHD. In one study, long-term exposure to injustice was assessed by repeated measurements over a 3-year period with a 5-item scale, and the average of these measurements was used in the analysis (8). The second study assessed justice with a single-item measure measured at a single point in time (15).

\section{Assessment of coronary heart disease}

Among the included studies, the duration of mean follow-up varied between 4 to 26 years. For the job-strain model, the outcome definitions included diagnoses of CHD in hospital or mortality records $(39,42-45,49)$ or 
recorded death from cardiovascular disease (CVD) in national mortality registers $(41,43)$. In the Whitehall II study, self-reported angina was included in the outcome in addition to medical records (45), and the outcome in the nurses' health study was self-reported myocardial infarction confirmed by medical records (definite or probable myocardial infarction) and next-of-kin or postal-authorities-reported CHD deaths ascertained by records of the National Death Index (38). The outcome

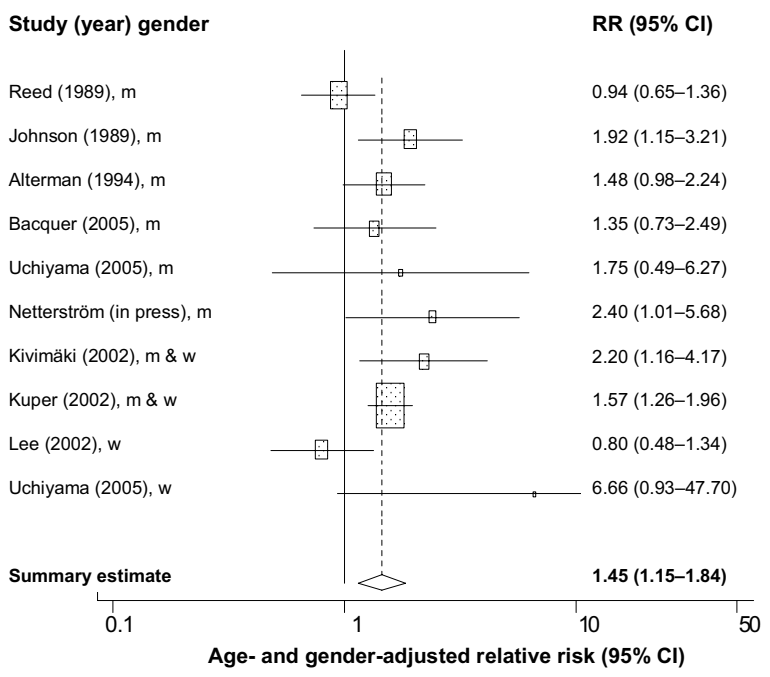

Figure 3. Relative risk (RR) of incident coronary heart disease and cardiovascular events and its summary estimate for the prospective cohort studies on the job-strain model by gender. (95\% Cl = 95\% confidence interval, $m=$ male study population, $f=$ female study population)

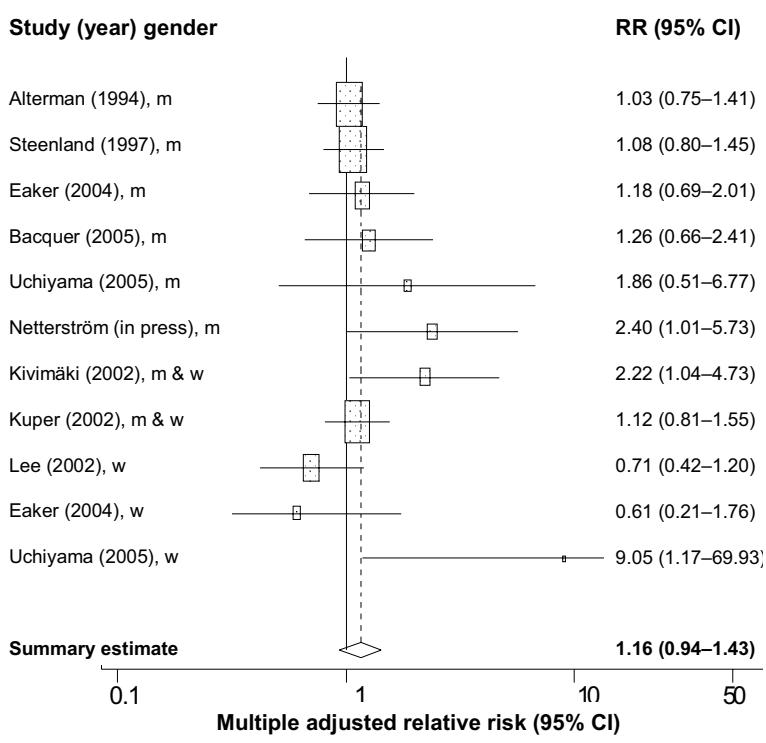

Figure 4. Multiple adjusted relative risk of incident coronary heart disease and cardiovascular events and its summary estimate for the prospective cohort studies on the job-strain model by gender. $(95 \% \mathrm{Cl}=$ $95 \%$ confidence interval, $m=$ male study population, $f=$ female study population) in the hypertension follow-up group study was CVD events indicated as initial cerebral hemorrhage, cerebral infarction, subarachnoidal hemorrhage, myocardial infarction, heart failure, aortic aneurysmal rupture, or sudden death (46). In the Honolulu heart program study, data for the outcome included hospitalization and mortality data combined with information from obituary notices in local newspapers, a less-convincing outcome measure (40).

The studies of the ERI model defined their outcomes as self-reported angina or self-reported physician-diagnosed ischemia (48), expert judgments on definite or probable fatal or nonfatal myocardial infarction or sudden cardiac death (6), recorded deaths from CVD from a nationwide mortality register (43), and recorded CHD death, a first nonfatal myocardial infarction or self-reported or definite angina (47).

The two outcomes for the organizational injustice model were the incidence of CHD (defined as a CHD death, a recorded first nonfatal myocardial infarction, or definite angina) (8) and recorded CVD death from a nationwide mortality register (15).

\section{Summary estimates of relative risk for coronary heart disease}

An age- and gender-adjusted summary estimate across all of the job-strain studies suggested a risk ratio of 1.43 [95\% confidence interval (95\% CI) $1.15-1.84$ ] for a combination of high work demands and low job control (figure 3). Eight of the ten individual studies reported a significant or nonsignificant positive association between job strain and CHD, but, in the reports from the Honolulu heart program (40) and the nurses' health study (38), there was a nonsignificant negative association. After multiple adjustments for risk factors and potential mediators, the overall summary estimate of the relative risk (RR) decreased to 1.16 (95\% CI 0.94-1.43) (figure 4).

The summary estimate for the ERI model showed a 1.58 -fold (95\% CI 0.84-2.97) age- and gender-adjusted excess risk for employees reporting high effort and low reward (table 3). When Kuper et al (47) was replaced by Bosma et al (48), the excess risk was higher (RR 2.52, 95\% CI 1.63-3.90). Multiple adjustments did not reduce the overall relative risk for effort-reward imbalance $(2.05,95 \%$ CI 0.97-4.32 with Kuper; 2.51, 95\% CI 1.58-3.90 with Bosma).

The two studies of organizational injustice and CHD reported an age- and gender-adjusted relative risk of 1.62 (95\% CI 1.24-2.13) for organizational injustice (table 3). This risk remained statistically significant after additional adjustments for other risk factors including job strain and effort-reward imbalance (RR 1.47, 95\% CI 1.12-1.95). 


\section{Test of heterogeneity}

We observed heterogeneity between studies regarding the relative risks for job strain $(\mathrm{Q}=17.5, \mathrm{df}=9, \mathrm{P}=0.04$ in age- and gender-adjusted model; $\mathrm{Q}=15.4, \mathrm{df}=10$, $\mathrm{P}=0.12$ in multiple-adjusted model) and effort-reward imbalance $(\mathrm{Q}=3.9, \mathrm{df}=1, \mathrm{P}<0.05$ in age- and gender-adjusted model; $\mathrm{Q}=6.4, \mathrm{df}=2, \mathrm{P}=0.04$ in multiple-adjusted model). It was not possible to perform this test for the organizational injustice model due to the too small number of studies.

\section{Gender difference in the job strain-coronary heart dis- ease association}

A complete test of gender differences in the association between job strain and CHD was not possible because two studies reported only risk ratios for men and women in combination. However, in both of these studies, twothirds of the participants were men who also had the vast majority of CHD events. Thus it was possible to compare male or male-dominated samples with female samples.

For all of the male or male-dominated samples, a significant or nonsignificant positive association between job strain and CHD was reported, with the exception of samples from the Honolulu heart project study, which reported an inverse nonsignificant association (40). For the three female samples included in the meta-analysis, a nonsignificant inverse association between job strain and CHD was observed in two studies and a positive association was shown in one study with only two CVD events in the group of women with job strain. The formal test of gender difference failed to reach statistical significance $(\mathrm{P}=0.21$ for age-adjusted model, $\mathrm{P}=0.25$ for multiple-adjusted model).

Lack of studies with female samples prevented the test of gender differences for the ERI and injustice models.

\section{Test of publication bias}

We found some evidence for publication bias. The funnel plots for the age- and gender-adjusted and multipleadjusted job-strain studies appeared to be asymmetric, and the corresponding P-values for publication bias in Begg's test were 0.09 and 0.04, respectively. However, exclusion of the smaller studies $(<1000$ participants or $<50$ CHD or CVD events, 3 studies) $(43,46,49)$ had little effect on the overall excess risk related to job strain (the age- and gender-adjusted summary estimate 1.30, 95\% CI 1.01-1.68). The first study of the ERI model (6) reported a two times greater hazard ratio for effortreward imbalance than the later studies testing this
Table 3. Relative risk (RR) of incident coronary heart disease or cardiovascular mortality and its summary estimate in observational cohort studies on the effort-reward imbalance model and the organizational injustice model. $(95 \% \mathrm{Cl}=95 \%$ confidence interval)

\begin{tabular}{lcccc}
\hline Stress model & $\begin{array}{c}\text { Age- and gender- } \\
\text { adjusted }\end{array}$ & & $\begin{array}{c}\text { Multiple } \\
\text { adjusted a }\end{array}$ \\
\cline { 2 - 3 } \cline { 4 - 5 } & RR $95 \% \mathrm{Cl}$ & & RR $95 \% \mathrm{Cl}$ \\
\hline
\end{tabular}

Effort-reward imbalance

\begin{tabular}{|c|c|c|c|}
\hline Siegrist et al, 1990 (6) (men) & .. & & $4.531 .43-14.3$ \\
\hline $\begin{array}{l}\text { Bosma et al, } 1998 \text { (48) } \\
\text { (men, women) }\end{array}$ & 2.68 & $1.46-4.91$ & $2.151 .15-4.01$ \\
\hline $\begin{array}{l}\text { Kivimäki et al, } 2002 \text { (43) } \\
\text { (men, women) }\end{array}$ & 2.36 & $1.26-4.42$ & $2.42 \quad 1.02-5.73$ \\
\hline $\begin{array}{l}\text { Kuper et al, } 2002 \text { (47) (men, } \\
\text { women) }\end{array}$ & 1.22 & $1.01-1.46$ & $1.261 .03-1.55$ \\
\hline $\begin{array}{l}\text { Combined summary estimate ex- } \\
\text { cluding Bosma et al, } 1998(48)^{b}\end{array}$ & 1.58 & $0.84-2.97$ & $2.05 \quad 0.97-4.32$ \\
\hline $\begin{array}{l}\text { Combined summary estimate ex- } \\
\text { cluding Kuper et al, } 2002 \text { (47) }\end{array}$ & 2.52 & $1.63-3.90$ & $2.51 \quad 1.58-3.98$ \\
\hline \multicolumn{4}{|l|}{ Drganizational injustice } \\
\hline Kivimäki et al, 2005 (8) (men) & 1.54 & $1.10-2.13$ & $1.411 .01-1.96$ \\
\hline $\begin{array}{l}\text { Elovainio et al, in press (15) } \\
\text { (men, women) }\end{array}$ & 1.81 & $1.14-2.94$ & 16410 \\
\hline Combined summary estimate & 1.62 & $1.24-2.13$ & $1.471 .12-1.95$ \\
\hline
\end{tabular}

a The covariates varied between studies. See table 1 for adjustments in each study.

b Bosma et al (48) and Kuper et al (47) are from the same cohort, the first having a more comprehensive assessment of effort-reward imbalance, but the latter having a more objective assessment of outcome. Thus two meta-analyses were conducted.

model $(43,47)$, but no evidence was found for publication bias ( $\mathrm{P}=0.32$ in Begg's test), and exclusion of the first ERI study did not alter the summary estimate (RR for effort-reward imbalance 1.52, 95\% CI 0.85-2.70, with Kuper et al and 2.24, 95\% CI 1.35-3.71, with Bosma). The two studies of the organizational injustice model provided similar hazard ratios for injustice. All of these findings suggested that publication bias was unlikely to have substantially distorted the findings of our meta-analysis.

\section{Discussion}

Work stress is currently not included in the American Heart Association list of established risk factors for CHD, but individual response to stress is acknowledged as a potential contributing factor (www.americanheart.org). According to our meta-analysis of prospective cohort studies published by January 2006, work stress is associated with about a 50\% excess risk of CHD. To our knowledge, this is the first meta-analysis on the best evidence available on this topic, and it was based on 14 studies, of which 6 were not included in the previous 
narrative reviews $(16,26-29)$. An advantage of metaanalyses when compared with narrative reviews is that they provide an objective summary of the existing evidence.

Only three independent prospective cohort studies tested the ERI model $(6,43,47,48)$, and two studies tested the organizational injustice model $(8,9)$. All of these studies reported a positive association between work stress and CHD that was robust to adjustment for other risk factors. The number of identified independent prospective cohort studies assessing the job-strain model was 11 , relating to a 7-10 times greater total population than that for the other work-stress models (37-46). Although the overall summary estimate of the age- and gender-adjusted relative risk for CHD among employees with job strain suggested increased risk, some single studies reported null findings.

The reasons for mixed findings on job strain are unclear, but at least the following four issues may have contributed to inconsistent evidence. First, two of the three studies with a lower ratio of CHD risk for highstrain employees (compared with those with low strain) were related to female samples $(38,39)$. This inverse association was not replicated in a study of cardiovascular events among Japanese women (46), but, because only two cardiovascular events were recorded in the high-strain group, that finding remains open to chance. The stress of unpaid work at home (eg, child care) may be particularly important for women because they still carry a larger share of the responsibility for doing domestic duties $(50,51)$. For example, findings from the Whitehall II study suggest that low control at home predicts CHD among women but not among men (52), and a Swedish study showed that a combination of stressful conditions at work and at home predicted perceived symptoms among women, whereas, for men, symptoms were more strongly determined by work stress alone (53). Although the formal test of gender difference failed to reach statistical significance in this meta-analysis, it is possible that work stress is a less powerful predictor of CHD among women than among men.

Second, all studies with null findings assessed job strain at one point in time only. As CHD develops over a long time span, long-term rather than short-term levels of job strain are assumed to have an impact on CHD incidence. For employees with stable strain, a single time measurement may provide an accurate estimate of long-term strain, but this is not necessarily the case for others with changing job-strain levels. Data from the British Whitehall II study suggest that the use of singletime exposure measures may underestimate the status of long-term job strain as a CHD risk factor (25). Indeed, the regression dilution-corrected excess risk of CHD for job strain was 30\% higher than the corresponding uncorrected estimate in these data.
Third, bias and measurement error may have contributed to false negative results. Two cohorts with null findings included participants at postretirement age [the maximum age was 71 years in the nurses' health study (38) and 77 years in the Framingham offspring study (39)], and, therefore, the likelihood of recall and survivor biases was increased. In the nurses' health study, 146 incident CHD cases were detected after the assessment of job strain. However, this assessment took place 16 years after the baseline and involved only $29 \%$ of the baseline cohort, excluding over 7000 participants who had a diagnosis of CHD, as well as 38000 baseline participants who were no longer working (38). If job strain predicts an increased risk of CHD and retirement $(16,27,54)$, this selective inclusion has a potential for biasing results towards the null. The third study with negative findings, the Honolulu heart program study, used imputed occupation-based job-strain scores derived from United States data as a whole to men of Japanese ancestry in Hawaii (40). The identification of incident CHD cases was, in part, based on obituary notices in local newspapers. Thus both exposure and outcome may have been imprecisely measured.

Fourth, it is also important to consider type I error (false positive) as a source of mixed findings (ie, the possibility that the observed positive associations between work stress and CHD are spurious), the null findings representing the true estimates. Publication bias may increase the risk of false positive findings, but we found little evidence suggesting that this type of bias would have distorted findings in our meta-analysis. Confounding due to some unmeasured third factors (eg, risk factors from the preemployment period) may artificially inflate associations, a possibility that cannot fully be ruled out in any observational study. However, there is some evidence suggesting that preemployment factors do not substantially confound the association between job strain and CHD risk (55).

\section{Directions of future research}

Further studies with more sophisticated assessment strategies are needed to develop a more complete picture of the role of work stress in the etiology of CHD. There has been little standardization in the assessment of work stress, as the survey instruments have varied between studies and many studies have made modifications to the scales. Moreover, the standard questionnaires for the ERI and organizational injustice models have only recently been published; thus the existing follow-up studies on these models rely on preliminary scales or secondary analyses of data originally collected for other primary purposes. Thus replications of work-stress studies with standard instruments $(11,56-58)$ would be vital to ensure independent assessment of exposure and outcome. 
At the same time, however, it is important to recognize that worklife is under continuous change, and this process causes variation in the relative importance of existing stressors and the possibility of new stressors emerging. An interdisciplinary approach may help to update stress models in the future. The job-strain model was developed in the context of industrialization in parallel to a widely applied work-motivation theory with some core aspects of work that are close to the job-control concept (ie, task variety, and autonomy) $(59,60)$. The ERI model shares elements with the distributive justice model, another work motivation theory (10), and taps features of postmodern flexible worklife, such as temporary employment and job insecurity (61). The most recent developments in work motivation theories involve procedural and relational justice at work (11, 13 ), which has been shown to be an important moderator of employee responses (62-65). A further parallel between work motivation theories and stress models is the application of the organizational injustice concept in studies of stress as an etiological factor for CHD.

The pathways through which work stress may elicit harmful effects on CHD have remained unclear. This meta-analysis showed that the association between work stress, as indicated by job strain, and CHD substantially decreased after adjustment for covariates, such as socioeconomic position, body mass index, blood pressure, cholesterol concentration, smoking, and sedentary lifestyle. While the interpretation of this finding is not unambiguous, the decrease may provide information about factors that mediate the association between work stress and CHD. Stress has been associated with sleep disturbances (20), increased smoking intensity (21), reduced leisure-time physical activity (22), unhealthy diet (23), increased weight gain and obesity $(66,67)$, metabolic and hemostatic disturbances $(18,68)$, reduced heart rate variability and vagal tone $(9,68,69)$, early atherosclerosis (70), impaired inflammatory and immune response $(71,72)$, accelerated cellular aging $(19)$, and other risk factors $(1,17)$. To determine whether these associations indicate stress mediators, studies directly linking epidemiologic evidence with subsequent intermediate biological and behavioral mechanisms and with cardiovascular endpoints are needed.

Attenuation of the stress-CHD association after adjustments may also imply confounding and a risk marker status for work stress. The long latency period between some distant risk factors and manifest $\operatorname{CHD}(73,74)$ and the fact that CHD is a multietiological disease make it difficult to distinguish between single causal risk factors and risk markers, although this distinction is essential in terms of policy implications. Favorable change in causal risk factors, but not in risk markers, would reduce the risk of CHD and therefore form the target for interventions. In the future, attempts to carry out large-scale work stress intervention studies with long follow-up periods would be of vital importance, as they may increase the understanding of both causality and means of prevention. Additional studies taking advantage of naturally occurring worklife changes could also be helpful. One example of such changes is organizational downsizing, a proxy measure for increases in job strain and effort-reward imbalance among those who keep their jobs (75). In a recent study, downsizing was associated with an increased risk of CVD mortality among such employees, and the greatest excess risk was found in the years immediately following the personnel reductions (76). This time-dependent effect pattern supports a causal, rather than a confounded, association between downsizing and CVD mortality, but further research is needed for confirmation.

Finally, little research has been done to establish risk profiles for people exposed to work stress. The same environmental challenges or stressors are not likely to induce similar stress reactions in all people, but factors determining groups at greatest risk of CHD under stress have remained unclear. Thus future research should also focus on interactions between work stress, genetic predispositions, and health behavior to improve the predictive validity of stress models.

\section{Concluding remarks}

Traditional occupational hazards, such as exposures to toxic chemicals, cold, and noise, may account for only part of the effect of work on health. Work stress refers to the aspects of work design, organization, and management, and their social and organizational contexts, that have the potential to cause harm to employee health. This paradigm, in addition to the conventional physicochemical approach, is suggested to form an essential part of contemporary occupational health research. We found an overall predictive association between work stress and CHD with about 50\% excess risk among stressed employees, but we also acknowledged several methodological limitations in the existing evidence. A meta-analysis provides an objective summary of current evidence, but is open to the same threats of validity as the single studies that form the combined data base. Thus further research in contemporary worklife is needed to clarify the role of work stress in the etiology of CHD.

\section{Acknowledgments}

This study was supported by the Finnish Work Environment Fund and the Academy of Finland (projects 117604, 105195, and 110451). 
Dr Kouvonen was a visiting scientist at the University of Nottingham when this paper was prepared.

\section{References}

1. McEwen BS. Protective and damaging effects of stress mediators. N Engl J Med. 1998;338:171-9.

2. Karasek RA. Job demands, job decision latitude and mental strain: implications for job redesign. Admin Sci Q. 1979;24:285-307.

3. Karasek R, Baker D, Marxer F, Ahlbom A, Theorell T. Job decision latitude, job demands, and cardiovascular disease: a prospective study of Swedish men. Am J Public Health. 1981;71:694-705.

4. Karasek R, Theorell T. Healthy work: stress, productivity, and the reconstruction of working life. New York (NY): Basic Books; 1990.

5. Johnson JV, Hall EM. Job strain, work place social support, and cardiovascular disease: a cross-sectional study of a random sample of the Swedish working population. Am J Public Health. 1988;78:1336-42.

6. Siegrist J, Peter R, Junge A, Cremer P, Seidel D. Low status control, high effort at work and ischemic heart disease: prospective evidence from blue-collar men. Soc Sci Med. 1990;31:1127-34.

7. Siegrist J. Adverse health effects of high-effort/low-reward conditions. J Occup Health Psychol. 1996;1:27-41.

8. Kivimaki M, Ferrie JE, Brunner E, Head J, Shipley MJ, Vahtera J, Marmot MG. Justice at work and reduced risk of coronary heart disease among employees: the Whitehall II Study. Arch Intern Med. 2005;165:2245-51.

9. Elovainio M, Kivimäki M, Puttonen S, Lindholm H, Pohjonen T, Sinervo T. Organizational injustice and impaired cardiovascular regulation among female employees. Occup Environ Med. 2006;63:141-44.

10. Brockner J, Wiesenfeld BM. An integrative framework for explaining reactions to decisions: interactive effects of outcomes and procedures. Psychol Bull. 1996;120:189-208.

11. Moorman RH. Relationship between organizational justice and organizational citizenship behaviors: do fairness perceptions influence employee citizenship? J Appl Psychol. 1991;76:845-55.

12. Fehr E, Fischbacher U. The nature of human altruism. Nature. 2003;425:785-91.

13. Miller DT. Disrespect and the experience of injustice. Annu Rev Psychol. 2001;52:527-53.

14. Brosnan SF, De Waal FB. Monkeys reject unequal pay. Nature. 2003;425:297-9.

15. Elovainio M, Leino-Arjas P, Vahtera J, Kivimäki M. Justice at work and cardiovascular mortality: a prospective cohort study. J Psychosom Res. 2006;61:271-4.

16. Hemingway H, Marmot M. Evidence based cardiology: psychosocial factors in the aetiology and prognosis of coronary heart disease. Systematic review of prospective cohort studies. BMJ. 1999;318:1460-7.

17. Brunner E. Stress mechanisms in coronary heart disease. In: Stansfeld SA, Marmot MG, editors. Stress and the heart: psychosocial pathways to coronary heart disease. Williston (VT): BMJ Books; 2002. p 181-99.

18. Chandola T, Brunner E, Marmot M. Chronic stress at work and the metabolic syndrome: prospective study. BMJ.
2006;332:521-5.

19. Epel ES, Blackburn EH, Lin J, Dhabhar FS, Adler NE, Morrow JD, Cawthon RM. Accelerated telomere shortening in response to life stress. Proc Natl Acad Sci USA. 2004;101: 17312-5.

20. Kalimo R, Tenkanen L, Härmä M, Poppius E, Heinsalmi P. Job stress and sleep disorders: findings from the Helsinki Heart Study. Stress Med. 2000;16:65-75.

21. Kouvonen A, Kivimaki M, Virtanen M, Pentti J, Vahtera J. Work stress, smoking status, and smoking intensity: an observational study of 46,190 employees. J Epidemiol Community Health. 2005;59:63-9.

22. Kouvonen A, Kivimaki M, Elovainio M, Virtanen M, Linna A, Vahtera J. Job strain and leisure-time physical activity in female and male public sector employees. Prev Med. 2005;41:532-9.

23. Wardle J, Gibson EL. Impact of stress on diet: processes and implications. In: Stansfeld S, Marmot M, editors. Stress and the heart: psychosocial pathways to coronary heart disease. London: BMJ Books; 2002:124-49.

24. Macleod J, Davey Smith G, Heslop P, Metcalfe C, Carroll D, Hart C. Psychological stress and cardiovascular disease: empirical demonstration of bias in a prospective observational study of Scottish men. BMJ. 2002;324:1247-51.

25. Kivimäki M, Head J, Ferrie JE, Brunner E, Marmot MG, Vahtera $\mathbf{J}$, et al. Why is evidence on job strain and coronary heart disease mixed?: an illustration of measurement challenges in the Whitehall II study. Psychosom Med. 2006;68: 398-401.

26. Kuper H. Systematic review of prospective cohort studies of psychosocial factors in the etiology and prognosis of coronary heart disease. Semin Vasc Med. 2002;2:267-314.

27. Belkic KL, Landsbergis PA, Schnall PL, Baker D. Is job strain a major source of cardiovascular disease risk? Scand J Work Environ Health. 2004;30:85-128.

28. van Vegchel N, de Jonge J, Bosma H, Schaufeli W. Reviewing the effort-reward imbalance model: drawing up the balance of 45 empirical studies. Soc Sci Med. 2005;60:1117-31.

29. Everson-Rose SA, Lewis TT. Psychosocial factors and cardiovascular diseases. Annu Rev Public Health. 2005;26:469_ 500 .

30. Egger M, Davey Smith G, Altman DG. Systematic reviews in health care: meta-analysis in context. 6 ed. Cornwall (UK): BMJ Publishing Group; 2005.

31. Stroup DF, Berlin JA, Morton SC, Olkin I, Williamson GD, Rennie D, et al. Meta-analysis of observational studies in epidemiology: a proposal for reporting. JAMA. 2000;283: 2008-12.

32. Karasek RA, Theorell T, Schwartz JE, Schnall PL, Pieper CF, Michela JL. Job characteristics in relation to the prevalence of myocardial infarction in the US Health Examination Survey (HES) and the Health and Nutrition Examination Survey (HANES). Am J Public Health. 1988;78:910-8.

33. Woodward M. Epidemiology: study design and data analysis. Boca Raton (FL): Chapman \& Hall; 2005.

34. Sterne JAC, Bradburn MJ, Egger M. Meta-analysis in Stata. In: Egger M, Davey Smith G, Altman DG, editors. Systematic reviews in health care: meta-analysis in context. 6th ed. London (UK): BMJ Publicing Group; 2005. p 347-72.

35. Egger M, Davey Smith G, Schneider M, Minder C. Bias in meta-analysis detected by a simple, graphical test. BMJ. 1997;315:629-34.

36. Begg CB, Mazumdar M. Oprating characteristics of a rank correlation test for publication bias. Biometrics. 1994;50: 
$1088-101$.

37. Steenland K, Johnson J, Nowlin S. A follow-up study of job strain and heart disease among males in the NHANES1 population. Am J Ind Med. 1997;31:256-60.

38. Lee S, Colditz G, Berkman L, Kawachi I. A prospective study of job strain and coronary heart disease in US women. Int J Epidemiol. 2002;31:1147-53.

39. Eaker ED, Sullivan LM, Kelly-Hayes M, D'Agostino RB Sr, Benjamin EJ. Does job strain increase the risk for coronary heart disease or death in men and women?: the Framingham Offspring study. Am J Epidemiol. 2004;159:950-8.

40. Reed DM, LaCroix AZ, Karasek RA, Miller D, MacLean CA. Occupational strain and the incidence of coronary heart disease. Am J Epidemiol. 1989;129:495-502.

41. Johnson JV, Hall EM, Theorell T. Combined effects of job strain and social isolation on cardiovascular disease morbidity and mortality in a random sample of the Swedish male working population. Scand J Work Environ Health. 1989;15:2719.

42. Alterman T, Shekelle RB, Vernon SW, Burau KD. Decision latitude, psychologic demand, job strain, and coronary heart disease in the Western Electric Study. Am J Epidemiol. 1994;139:620-7.

43. Kivimäki M, Leino-Arjas $\mathrm{P}$, Luukkonen R, Riihimäki H, Vahtera J, Kirjonen J. Work stress and risk of cardiovascular mortality: prospective cohort study of industrial employees. BMJ. 2002;325:857-61.

44. Kuper H, Marmot M. Job strain, job demands, decision latitude, and risk of coronary heart disease within the Whitehall II study. J Epidemiol Community Health. 2003;57:147-53.

45. De Bacquer D, Pelfrene E, Clays E, Mak R, Moreau M, de Smet $\mathrm{P}$, et al. Perceived job stress and incidence of coronary events: 3-year follow-up of the Belgian Job Stress Project cohort. Am J Epidemiol. 2005;161:434-41.

46. Uchiyama S, Kurasawa T, Sekizawa T, Nakatsuka H. Job strain and risk of cardiovascular events in treated hypertensive Japanese workers: hypertension follow-up group study. J Occup Health. 2005;47:102-11.

47. Kuper H, Singh-Manoux A, Siegrist J, Marmot M. When reciprocity fails: effort-reward imbalance in relation to coronary heart disease and health functioning within the Whitehall II study. Occup Environ Med. 2002;59:777-84.

48. Bosma H, Peter R, Siegrist J, Marmot M. Two alternative job stress models and the risk of coronary heart disease. Am J Public Health. 1998;88:68-74.

49. Netterström B, Kristensen TS, Sjöl A. Psychological job demands increase the risk of ischaemic heart disease: a 14-year cohort study of employed Danish men. Eur J Cardiovasc Prev Rehabil. 2006;13:414-20.

50. Lundberg U, Mardberg B, Frankenhaeuser M. The total workload of male and female white collar workers as related to age, occupational level, and number of children. Scand J Psychol. 1994;35:315-27.

51. Väänänen A, Kevin MV, Ala-Mursula L, Pentti J, Kivimäki M, Vahtera J. The double burden of and negative spillover between paid and domestic work: associations with health among men and women. Women Health. 2004;40:1-18.

52. Chandola T, Kuper H, Singh-Manoux A, Bartley M, Marmot $\mathrm{M}$. The effect of control at home on CHD events in the Whitehall II study: gender differences in psychosocial domestic pathways to social inequalities in CHD. Soc Sci Med. 2004:58:1501-9.

53. Krantz G, Berntsson L, Lundberg U. Total workload, work stress and perceived symptoms in Swedish male and female white-collar employees. Eur J Public Health. 2005;15:209_ 14.

54. Krause N, Lynch J, Kaplan GA, Cohen RD, Goldberg DE, Salonen JT. Predictors of disability retirement. Scand J Work Environ Health. 1997;23:403-13.

55. Kivimäki M, Hintsanen M, Keltikangas-Järvinen L, Elovainio M, Pulkki-Raback L, Vahtera J, et al. Early risk factors, job strain and atherosclerosis among men in their 30s: the cardiovascular risk in young Finns study. Am J Public Health. In press.

56. Siegrist J, Starke D, Chandola T, Godin I, Marmot M, Niedhammer I, et al. The measurement of effort-reward imbalance at work: European comparisons. Soc Sci Med. 2004;58:1483-99.

57. Karasek R, Brisson C, Kawakami N, Houtman I, Bongers P, Amick B. The Job Content Questionnaire (JCQ): an instrument for internationally comparative assessments of psychosocial job characteristics. J Occup Health Psychol. 1998;3: 322-55.

58. Kivimäki M, Elovainio M, Vahtera J, Ferrie JE. Organisationa justice and health of employees: prospective cohort study. Occup Environ Med. 2003;60:27-33.

59. Karasek RA, Theorell T. Stress, productivity and reconstruction of working life. New York (NY): Basic Books; 1990.

60. Hackman JR, Oldham GR. Work redesign. Reading (MA): Addison-Wesley; 1980.

61. Siegrist J, Peter R. Threat to occupational status control and cardiovascular risk. Isr J Med Sci. 1996; 32:179-84.

62. Siegel PA, Post C, Brockner J, Fishman AY, Garden C. The moderating influence of procedural fairness on the relationship between work-life conflict and organizational commitment. J Appl Psychol. 2005;90:13-24.

63. Elovainio M, Kivimäki M, Vahtera J. Organizational justice: evidence of a new psychosocial predictor of health. Am J Public Health. 2002;92:105-8.

64. Kivimäki M, Elovainio M, Vahtera J, Virtanen M, Stansfeld SA. Association between organizational inequity and incidence of psychiatric disorders in female employees. Psychol Med. 2003;33:319-26.

65. Elovainio M, Kivimäki M, Helkama K. Organization justice evaluations, job control, and occupational strain. J Appl Psychol. 2001;86:418-24.

66. Kivimäki M, Head J, Ferrie JE, Shipley MJ, Brunner E, Vahtera J, et al. Work stress, weight gain and weight loss: evidence for bidirectional effects of job strain on body mass index in the Whitehall II study. Int J Obes. 2006;30:982-7.

67. Dallman MF, Pecoraro N, Akana SF, La Fleur SE, Gomez F, Houshyar H, et al. Chronic stress and obesity: a new view of "comfort food". Proc Natl Acad Sci USA. 2003;100:11696701.

68. Vrijkotte TG, van Doornen LJ, de Geus EJ. Work stress and metabolic and hemostatic risk factors. Psychosom Med. 1999;61:796-805.

69. Vrijkotte TG, van Doornen LJ, de Geus EJ. Effects of work stress on ambulatory blood pressure, heart rate, and heart rate variability. Hypertension. 2000;35:880-6.

70. Hintsanen M, Kivimäki M, Elovainio M, Pulkki-Råback L, Keskivaara P, Juonala M, et al. Job strain and early atherosclerosis: the cardiovascular risk in young Finns study. Psychosom Med. 2005;67:740-7.

71. Cohen S, Tyrrell DA, Smith AP. Psychological stress and susceptibility to the common cold. N Engl J Med. 1991;325:606-12.

72. Kiecolt-Glaser JK, Marucha PT, Malarkey WB, Mercado AM, 
Glaser R. Slowing of wound healing by psychological stress. Lancet. 1995;346:1194-6.

73. Raitakari OT, Juonala M, Kähönen M, Taittonen L, Laitinen T, Mäki-Torkko N, et al. Cardiovascular risk factors in childhood and carotid artery intima-media thickness in adulthood: the Cardiovascular Risk in Young Finns Study. JAMA. 2003;290:2277-83.

74. Galobardes B, Smith GD, Lynch JW. Systematic review of the influence of childhood socioeconomic circumstances on risk for cardiovascular disease in adulthood. Ann Epidemiol.
2005;16:91-104.

75. Kivimäki M, Vahtera J, Pentti J, Ferrie JE. Factors underlying the effect of organisational downsizing on health of employees: longitudinal cohort study. BMJ. 2000;320:971-5.

76. Vahtera J, Kivimäki M, Pentti J, Linna A, Virtanen M, Virtanen $\mathrm{P}$, et al. Organisational downsizing, sickness absence, and mortality: 10-town prospective cohort study. BMJ. 2004;328:555.

Received for publication: 30 January 2006 